Shellfish Immunology

Elsevier Editorial System(tm) for Fish and

Manuscript Draft

Manuscript Number: FSIM-D-20-00614R1

Title: Microalgal extracts induce larval programming and modify growth and the immune response to bioactive treatments and LCDV in senegalese sole post-larvae.

Article Type: Full Length Article

Keywords: beta-glucans, immune response, LCDV, microalgae, programming, Senegalese sole, virus

Corresponding Author: Dr. Manuel Manchado, PhD

Corresponding Author's Institution: IFAPA

First Author: Carlos Carballo, PhD

Order of Authors: Carlos Carballo, PhD; Ana Patricia Mateus, PhD; Claudia Maya; Lalia Mantecon; Power DM, PhD; Manuel Manchado, PhD

Abstract: Immunostimulants are key molecules in aquaculture since they heighten defensive responses and protection against pathogens. The present study investigated the treatment of Senegalese sole larvae with a whole-cell crude extract of the microalgae Nannochloropsis gaditana (Nanno) and programming of growth and the immune system. Larvae at hatch were treated with the Nanno extracts for $2 \mathrm{~h}$ and thereafter were cultivated for 32 days post-hatch (dph) in parallel with an untreated control group (CN). Dry weight and length at 21 days post-hatch (dph) were higher in post-larvae of the Nanno than CN group. These differences in weight were later confirmed at $32 \mathrm{dph}$. To evaluate changes in the immune response associated with Nanno-programming treatments, the Nanno and CN post-larvae were supplied with two bioactive compounds yeast betaglucan (Y) and a microalga extract from the diatom Phaeodactylum tricornutum (MAe). The bioactive treatments were administrated to the treatment groups through the live prey (artemia metanauplii, 200 artemia $\mathrm{mL}-1$ ) enriched for $30 \mathrm{~min}$ with $\mathrm{MAe}$ or $\mathrm{Y}$ (at $2 \mathrm{mg} \mathrm{mL}-1 \mathrm{SW}$ ) or untreated prey in the case of the negative control (SW). The effect of the treatments was assessed by monitoring gene expression, enzyme activity and mortality over 48h. The post-larvae sole supplied with the bioactive compounds $Y$ and MAe had increased mortality at $48 \mathrm{~h}$ compared to the SW group. Moreover, mortality was higher in Nanno-programmed than CN postlarvae. Lysozyme and total anti-protease enzymatic activities at 6 and $24 \mathrm{~h}$ after the start of the trial were significantly higher in the Nanno and MAe supplied post-larvae compared to their corresponding control (CN and SW, respectively). Immune gene transcripts revealed that illb, cxc10 and mx mRNAs were significantly different between Nanno and CN postlarvae at 6 and $24 \mathrm{~h}$. Moreover, the expression of illb, tnfa, cxc10, irf3, irf7 and mx was modified by bioactive treatments but with temporal differences. At $48 \mathrm{~h}$ after bioactive treatments, $Y$ and SW post-larvae were challenged with the lymphocystis disease virus (LCDV). No difference existed in viral copy number between programming or bioactive treatment groups at 3, 6 and 24 h after LCDV challenge although the total number of copies reduced with time. Gene expression profiles in the LCDV-challenged 
group indicated that post-larvae triggered a wide defensive response compared to SWC $24 \mathrm{~h}$ after challenge, which was modulated by programming and bioactive compound treatments. Cluster analysis of expressed genes separated the SW and $\mathrm{Y}$ groups indicating long-lasting effects of yeast beta-glucan treatment in larvae. A noteworthy interaction between Nannoprogramming and Y-treatment on the regulation of antiviral genes was observed. Overall, the data demonstrate the capacity of microalgal crude extracts to modify sole larval plasticity with long-term effects on larval growth and the immune responses.

Research Data Related to this Submission

There are no linked research data sets for this submission. The following reason is given:

Data will be made available on request 


\section{Microalgal extracts induce larval programming and modify growth and the immune response to bioactive treatments and LCDV in Senegalese sole post-larvae}

Carlos Carballo ${ }^{\mathrm{a}, \mathrm{b}}$; Ana Patricia Mateus ${ }^{\mathrm{c}, \mathrm{d}}$; Claudia Maya ${ }^{\mathrm{e}}$; Lalia Mantecón ${ }^{\mathrm{e}}$; Deborah M. Power ${ }^{\mathrm{c} *}$; and Manuel Manchado ${ }^{\mathrm{a}, \mathrm{f}_{*}}$

${ }^{a}$ IFAPA Centro El Toruño, Junta de Andalucía, Camino Tiro Pichón s/n, 11500 El Puerto de Santa María, Cádiz, Spain

bUniversidad de Málaga, Departamento de Microbiologia, Campus de Teatinos, 29071, Malaga, Spain

${ }^{\mathrm{c}}$ Centre of Marine Sciences (CCMAR), Universidade do Algarve, Campus de Gambelas, 8005-139, Faro, Portugal

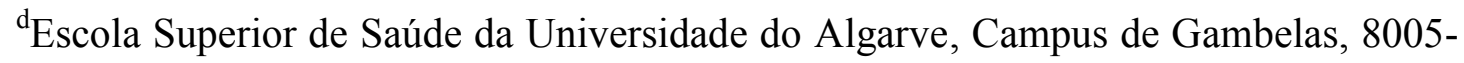
139, Faro, Portugal

${ }^{\mathrm{e}}$ Fitoplanton Marino S.L., 11500, El Puerto de Santa María, Spain

f "Crecimiento Azul", Centro IFAPA El Toruño, Unidad Asociada al CSIC”

Running title: Microalgal extracts induce trained immunity in sole

*Corresponding authors: Manuel Manchado. IFAPA Centro El Toruño. Camino Tiro de Pichón s/n. 11500 El Puerto de Santa María (Cádiz), Spain. Phone: +34 671532088. Fax: +34 856102033. Email: manuel.manchado@juntadeandalucia.es

Deborah M Power. CCMAR, Universidade do Algarve, Campus de Gambelas, 8005139 Faro, Portugal. Email: dpower@ualg.pt 


\begin{abstract}
Immunostimulants are key molecules in aquaculture since they heighten defensive responses and protection against pathogens. The present study investigated the treatment of Senegalese sole larvae with a whole-cell crude extract of the microalgae Nannochloropsis gaditana (Nanno) and programming of growth and the immune system. Larvae at hatch were treated with the Nanno extracts for $2 \mathrm{~h}$ and thereafter were cultivated for 32 days post-hatch (dph) in parallel with an untreated control group $(\mathrm{CN})$. Dry weight and length at 21 days post-hatch (dph) were higher in postlarvae of the Nanno than $\mathrm{CN}$ group. These differences in weight were later confirmed at $32 \mathrm{dph}$. To evaluate changes in the immune response associated with Nannoprogramming treatments, the Nanno and $\mathrm{CN}$ post-larvae were supplied with two bioactive compounds yeast $\beta$-glucan (Y) and a microalga extract from the diatom Phaeodactylum tricornutum (MAe). The bioactive treatments were administrated to the treatment groups through the live prey (artemia metanauplii, 200 artemia $\mathrm{mL}^{-1}$ ) enriched for $30 \mathrm{~min}$ with MAe or Y (at $2 \mathrm{mg} \mathrm{mL}^{-1} \mathrm{SW}$ ) or untreated prey in the case of the negative control (SW). The effect of the treatments was assessed by monitoring gene expression, enzyme activity and mortality over $48 \mathrm{~h}$. The post-larvae sole supplied with the bioactive compounds $\mathrm{Y}$ and MAe had increased mortality at $48 \mathrm{~h}$ compared to the SW group. Moreover, mortality was higher in Nanno-programmed than $\mathrm{CN}$ post-larvae. Lysozyme and total anti-protease enzymatic activities at 6 and $24 \mathrm{~h}$ after the start of the trial were significantly higher in the Nanno and MAe supplied post-larvae compared to their corresponding control (CN and SW, respectively). Immune gene transcripts revealed that $i l 1 b, c x c 10$ and $m x m R N A s$ were significantly different between Nanno and CN post-larvae at 6 and $24 \mathrm{~h}$. Moreover,
\end{abstract}


the expression of illb, tnfa, cxc10, irf3, irf7 and $m x$ was modified by bioactive treatments but with temporal differences. At $48 \mathrm{~h}$ after bioactive treatments, Y and SW post-larvae were challenged with the lymphocystis disease virus (LCDV). No difference existed in viral copy number between programming or bioactive treatment groups at 3,6 and $24 \mathrm{~h}$ after LCDV challenge although the total number of copies reduced with time. Gene expression profiles in the LCDV-challenged group indicated that post-larvae triggered a wide defensive response compared to SWC $24 \mathrm{~h}$ after challenge, which was modulated by programming and bioactive compound treatments. Cluster analysis of expressed genes separated the SW and $\mathrm{Y}$ groups indicating long-lasting effects of yeast $\beta$-glucan treatment in larvae. A noteworthy interaction between Nanno-programming and Y-treatment on the regulation of antiviral genes was observed. Overall, the data demonstrate the capacity of microalgal crude extracts to modify sole larval plasticity with long-term effects on larval growth and the immune responses.

Keywords: beta-glucans, immune response, LCDV, microalgae, programming, Senegalese sole, virus 


\section{Introduction}

Prebiotics are frequently used as feed supplements to strengthen immune competence in aquaculture. Functional polysaccharides or immunosaccharides, such as $\beta$-glucans, can directly stimulate the innate immune system when provided orally or injected and prevent disease outbreaks and mortality [1-3]. The $\beta$-glucans are complex polysaccharides present from bacteria to plants, structurally composed of glucose residues linked with $\beta$-D-glycosidic bonds. However, the position and distribution of these glycosidic bonds, the degree of branching, the molecular size and solubility characteristics confer specific chemical and bioactive properties to different $\beta$-glucans [3-5]. The branched 1,3/1,6 $\beta$-glucan variants from yeast and algae are the most frequent $\beta$-glucans used as feed ingredients in aquaculture $[3,6]$. A new function recently assigned to $\beta$-glucans, particularly the soluble $\beta$-glucan laminarin, is epigenetic programming of myeloid cells and promotion of innate immune memory in fish [7]. This cell priming by application of stimuli in early larval stages is associated with metabolic programming and an enhanced immune response and survival [7-9]. We recently demonstrated that Senegalese sole (Solea senegalensis) larvae can be programmed at hatch by thermal treatments to enhance growth performance in juveniles $[10,11]$. However, epigenetic reprograming of early life stages using microalgal extracts to modify growth and the immune response is still poorly explored.

The administration of $\beta$-glucans is reported to enhance immune system response and survival rates in several fish species challenged with different pathogens [3]. In Senegalese sole, particulate yeast $\beta$-glucans and microalgal extracts enriched in 
polysaccharides supplied by injection or oral administration activated an immunomodulatory response $[12,13]$. However, trained immunity induced by yeast $\beta$-glucans seems to be more specific since in the flatfish Scophthalmus maximus only protection against the bacteria Aeromonas salmonicida but not against viral haemorrhagic septicaemia virus (VHSV) was observed [14]. The lymphocystis disease virus (LCDV) is the causative agent of lymphocystis disease, a highly contagious disease responsible for high economic losses in the aquaculture industry worldwide [15]. Both probiotics and a herbal extract were reported to enhance the innate immune response and resistance to LCDV in P. olivaceus $[16,17]$. However, no information exists about the capacity of $\beta$-glucans to modulate the response to LCDV or if microalgal extracts can program the immune system.

The microalga Nannochloropsis gaditana is routinely used in hatcheries for larval rearing due to its nutritional value [18]. This microalgae is a rich source of bioactive molecules including polysaccharides (chrysolaminarin among others), polyunsaturated fatty acids and carotenoid pigments and the extracts have a cytoprotective effect on dermal fibroblasts under oxidative stress in vitro due to their potent antioxidant action $[19,20]$. In the present study $N$. gaditana whole-cell crude extracts (Nanno) were tested for their capacity to program sole larvae and their longterm effects on growth performance and the immune response in post-larvae were evaluated. Two bioactive treatments (yeast $\beta$-glucans and microalgal polysaccharideenriched extracts from the diatom Phaeodactylum tricornutum), and a challenge with LCDV were used to evaluate the antiviral immune response associated with Nanno programming. The results obtained provide data revealing microalgae can modulate fish larval plasticity with benefits for the aquaculture sector. 


\section{Material and methods}

\subsection{Microalgae extract and Yeast $\beta$-glucan sources}

All microalgae in this study were supplied by Fitoplancton Marino S.A (El Puerto de Santa Maria, Spain). The microalgae $N$. gaditana was initially grown indoors using autoclaved seawater (salinity $33 \mathrm{psu}$ ) enriched with filter-sterilized f/2 nutrients in 50 $\mathrm{mL}$ flasks. Filter-sterilized $\mathrm{CO}_{2}$ was continuously bubbled through the cultures maintained under standard conditions as previously reported [12]. Microalgae were inoculated in outdoor photobioreactors (PBRs) and cultivated under seasonal environmental conditions. After harvesting the microalgae $4 \mathrm{~h}$ after sunrise by continuous-flow centrifugation, they were frozen at $-20{ }^{\circ} \mathrm{C}$ and freeze-dried. To break the cells, the freeze-dried biomass was hydrated in sea water (SW) at a dilution of 1:4 (mass algae:SW) at $4^{\circ} \mathrm{C}$ and broken by high-pressure homogenization (Niro Soavi high-pressure homogenizer) at 1,200 bar using a flow of $9 \mathrm{~L} \mathrm{~h}^{-1}$. The fragmented microalgae were freeze-dried for preservation until use.

To prepare the whole-cell crude extract (Nanno), the freeze-dried microalgae were suspended in sterile sea water $(\mathrm{SW})$ at a ratio of 1:10 (w/v), respectively. The sterilized SW contained dimethyl sulfoxide (DMSO) at a final concentration of $0.01 \%$. The crude microalgae extract was thoroughly mixed and the suspension was stored at $4^{\circ} \mathrm{C}$ for $24 \mathrm{~h}$. Before use of the microalgae extracts for sole larval programming (within $30 \mathrm{~min}$ of preparation), the crude microalgae extract was centrifuged at $10,000 \times \mathrm{xg}$ for $15 \mathrm{~min}$ at $4^{\circ} \mathrm{C}$ and the soluble fraction was collected into a clean tube at $4^{\circ} \mathrm{C}$. 
A previously characterized microalgal polysaccharide-enriched extract (MAe) from the diatom, P. tricornutum $[12,13]$ and pure yeast $\beta$-glucan $(\mathrm{Y})$ (particulate $(1,3)$ $(1,6)$ - $\beta$-glucan $\left(\right.$ Yestimun $^{\circledR}$ ) 91\% pure from brewers' yeast, Quimivita, Barcelona, Spain; 42200P-030) were used for bioactive treatments of post-larval Senegalese sole.

\subsection{Virus collection and culture conditions}

The LCDV genotype VII was recovered from diseased animals (gilthead sea bream specimens) as previously described in $[21,22]$. The viral titer was calculated using a $\mathrm{TCID}_{50}$ assay and later confirmed by qPCR as previously reported [23, 24].

\subsection{Fish trial}

All procedures were authorized by the Bioethics and Animal Welfare Committee of IFAPA and given the registration number 26-11-15-374 by the National authorities for the regulation of animal care and experimentation.

For the larval reprogramming trial with Nanno, eggs collected from two independent tanks of wild sole broodstock held by IFAPA Centro El Toruño (El Puerto de Santa Maria, Cadiz, Spain) and CUPIMAR (San Fernando, Spain) were used. The fertilized eggs from each of the broodstock tanks were mixed, viable eggs separated by buoyancy (total 120,000 eggs) and incubated in a 500L-cylindroconical incubator at $20^{\circ} \mathrm{C}$ in an open circuit. Recently hatched larvae ( $\sim 1 \mathrm{~h}$ after hatching; 0 days posthatch (dph)) were collected and approximately 80,000 larvae were distributed equally between two buckets containing $4 \mathrm{~L}$ of seawater with slight aeration to facilitate larval dispersion. The sea water (SW) temperature was $20^{\circ} \mathrm{C}$, oxygen $6.5 \mathrm{ppm}$ and salinity 37 ppt. To one bucket containing hatched larvae $(0 \mathrm{dph})$ the Nanno crude extract 
(Nanno group) was added $\left(0.2 \mathrm{mg}\right.$ dry mass equivalent $\left.\mathrm{mL}^{-1} \mathrm{SW}\right)$ and for the control larvae $(\mathrm{CN})$ the Nanno crude extract was omitted. After $2 \mathrm{~h}$ treatment, the larvae were concentrated using a mesh, rinsed in clean seawater and then both experimental groups were distributed between triplicate 400-L tanks and cultured using standard hatchery protocols until the post-larval stage (after completion of metamorphosis)[10]. The $\mathrm{CN}$ and Nanno-exposed groups were sampled at premetamorphosis (7 and $12 \mathrm{dph})$, metamorphosis (16 dph) and at the end of metamorphosis (21 and $30 \mathrm{dph}$ ) to determine their dry weight and length. At each sampling point, individual larvae from each tank (20-25 larvae, each treatment in triplicate) were photographed to determine total length using ImageJ v1.47 software and oven dried $\left(24 \mathrm{~h}, 60^{\circ} \mathrm{C}\right)$ to estimate mean dry weight. At $32 \mathrm{dph}$, when postlarvae were sampled to carry out the trial to evaluate the immune response to bioactive treatments, since they were big enough the wet weight of individual larvae (19-24 larvae per tank, each treatment in triplicate) was measured.

To evaluate the immune response of the Nanno and CN post-larvae, a two-part trial was carried out as depicted in Figure 1. In brief, 720 post-larvae at 32 dph from the Nanno and CN groups were randomly distributed between 18 plastic trays $\left(360 \mathrm{~cm}^{2}\right.$, 80 post-larvae per tray) containing $1 \mathrm{~L}$ of filtered-sterile seawater (salinity $35 \mathrm{~g} \mathrm{~L}^{-1}, 6$ ppm oxygen at the beginning of the trial). The trays were placed in a temperaturecontrolled room to keep the water temperature at $20^{\circ} \mathrm{C}$. The post-larvae were kept in these conditions with still water and without an additional oxygen supply for $24 \mathrm{~h}$ and fed with artemia ( 1200 metanauplii/tray; 15 artemia/post-larva). The tank water was totally renewed ( $90 \%)$ with oxygen oversaturated (300\%) filtered seawater every 24 hrs. No mortality was registered at the beginning of the trial. 


\subsubsection{Treatments with MAe and Y}

The aim of the trial was to determine if Nanno programming in hatched larvae affected the immune response triggered by MAe and Y exposure in post-larvae. Both bioactive MAe and $\mathrm{Y}$ treatments were administrated to sole post-larvae (32 dph) through the live prey. The experimental groups maintained in triplicate trays were Nanno-MAe and Nanno-Y and CN-MAe and CN-Y. The artemia metanauplii (200 artemia $\mathrm{mL}^{-1}$ ) were enriched for $30 \mathrm{~min}$ with MAe or $\mathrm{Y}$ (at $2 \mathrm{mg} \mathrm{mL}^{-1} \mathrm{SW}$ ). The negative control groups were fed artemia metanauplii (200 artemia $\left.\mathrm{mL}^{-1}\right)$ prepared in SW only and consisted of Nanno-SW and CN-SW. After 30 min enrichment, the artemia were filtered through a mesh and suspended in clean seawater and the trial was started by supplying $\sim 1200$ metanauplii/tray to the post-larval sole (15 artemia/fish). No artemia were observed in the tanks $1 \mathrm{~h}$ after feeding and a second dose of Y- or MAe-enriched or control (SW) artemia was supplied to the post-larvae in the triplicate trays/treatment $4 \mathrm{~h}$ later. Fish sampling was carried out 6 and $24 \mathrm{~h}$ after the start of the experiment and used for gene expression and enzyme analysis $(\mathrm{n}=$ 6/group, 2 from each of the replicate trays for each of the analysis). The water in the trays remained without circulation throughout the trial but was totally renewed immediately after sampling at 6 and $24 \mathrm{~h}$ with oxygenated (300\% saturated) SW. The sole larvae were kept in the trays for $48 \mathrm{~h}$ after the start of the treatments and the mortality was recorded at 6,24 and $48 \mathrm{~h}$. For sampling, specimens were euthanized in an overdose $(300 \mathrm{ppm})$ of tricaine methane sulfonate (MS-222) and fixed in RNAlater (Invitrogen) for gene expression analysis (at 6 and 24h) or frozen on dry ice for enzyme analysis (at 6 and 24h). Thereafter, samples were stored at $-80{ }^{\circ} \mathrm{C}$ until use.

\subsubsection{Viral challenge}


After evaluating the responses of Nanno and $\mathrm{CN}$ sole post-larvae to $\mathrm{Y}$ and $\mathrm{MAe}$ exposure for $48 \mathrm{~h}$, they were challenged with LCDV to evaluate their antiviral response (Fig 1b). Due to the high mortality observed in the Nanno-MAe group it was excluded from the LCDV trial. The Nanno-Y, CN-Y, Nanno-SW and CN-SW postlarvae were pooled by treatment and redistributed between 8 new plastic trays (180 $\mathrm{cm}^{2}, 30$ fish/tray; 2 trays per treatment) containing oxygenated (300\%) filtered seawater. The four experimental groups of post-larvae were immediately challenged with LCDV supplied through the artemia as described in [22] (Fig. 1b). Briefly, artemia metanauplii were enriched with an LCDV suspension containing $5 \times 10^{4}$ $\operatorname{TCID}_{50} \mathrm{~mL}^{-1}$, for $30 \mathrm{~min}$, filtered, washed and resuspended in clean seawater. Then 15 infected metanauplii/post-larva (450 artemia/tank) were supplied to each of the 8 trays establishing four post-larvae groups: Nanno-Y-V, CN-Y-V, Nanno-SW-V and CN-SW-V). Matched groups not challenged by viral exposure were fed with noninfected artemia (15 metanauplii/post-larva, 2 trays), and designated Nanno-Y-SWC, CN-Y-SWC, Nanno-SW-SWC and CN-SW-SWC. Approximately $1 \mathrm{~h}$ after feeding when no artemia were observed in the trays, the seawater was totally renewed with clean sterile oxygenated seawater. Samples $(n=6 /$ treatment; $n=3 /$ tray $)$ of sole postlarvae were collected at 3, 6 and $24 \mathrm{~h}$ after LCDV-challenge for quantification of LCDV DNA copies and at $24 \mathrm{~h}$ for gene expression analysis. No mortality was registered up to $24 \mathrm{~h}$ after LCDV challenge.

\subsection{RNA isolation and gene expression analysis}

Total RNA for gene expression analysis was extracted from Nanno, CN, Nanno-Y, Nanno-MAe, Nanno-SW, CN-Y, CN-MAe and CN-SW (n = 4 per group) samples collected at 6 and 24h using an Isolate II RNA Mini Kit (Bioline). Individual larvae 
were homogenized in a Fast-prep FG120 instrument (Bio101) using Lysing Matrix D (Q-Bio-Gene) for $60 \mathrm{~s}$ at speed setting 6. The extracted total RNA was treated twice over 30 minutes with DNase I using the clean-up protocol according to the manufacturer's instructions. The extracted RNA was quantified using a Nanodrop ND-8000 (Thermo Scientific) and the integrity was assessed by agarose gel electrophoresis.

To isolate total RNA and DNA from post-larvae at $24 \mathrm{~h}$ after LCDV challenge $(\mathrm{n}=4$ per treatment), the TRIsure (Bioline) method was used as described in Carballo, et al. [22]. For post-larvae at 3 and $6 \mathrm{~h}$ after LCDV challenge only DNA was extracted (see section 2.6). RNA from the $24 \mathrm{~h}$ post-larvae (groups CN_SW_SWC, CN_Y_SWC, Nanno_SW_SWC, Nanno_Y_SWC, CN_SW_V, CN_Y_V, Nanno_SW_V, Nanno_Y_V) was extracted by homogenization in a Fast-prep FG120 instrument (Bio101) using Lysing Matrix D (Q-Bio-Gene) and TRI-Reagent (1 mL) for $60 \mathrm{~s}$ at speed setting 6. Chloroform $(0.2 \mathrm{ml})$ was added, incubated for $5 \mathrm{~min}$ at room temperature and then samples were centrifuged at $12,000 \mathrm{xg}, 4^{\circ} \mathrm{C}$ for $15 \mathrm{~min}$ and the aqueous phase was transferred to a column of Isolate II RNA Mini Kit (Bioline) and treated as describe above.

RNA was reverse-transcribed using an $i$ cript $^{\mathrm{TM}}$ cDNA Synthesis Kit (Bio-Rad) and qPCR assays were carried out using a CFX96 ${ }^{\mathrm{TM}}$ Real-Time System (Bio-Rad) in a 10$\mu \mathrm{l}$ reaction volume containing cDNA generated from $200 \mathrm{ng}$ of original RNA template, $300 \mathrm{nM}$ each of specific forward and reverse primers, and $5 \mu 1$ of SsoAdvanced ${ }^{\mathrm{TM}}$ Universal SYBR ${ }^{\circledR}$ Green Supermix (Bio-Rad). The primers used in the study have previously been published: illb, tnfa, clec, cxc10, irf7 [12], irf3 [21], $m x$ [25] $c d 4$ and $c d 8 a$ [22]. The qPCR amplification cycle was as follows: a first step 
of $7 \mathrm{~min}$ at $95^{\circ} \mathrm{C}$ for enzyme activation, followed by 40 cycles of $30 \mathrm{~s}$ at $95^{\circ} \mathrm{C}$ and $30 \mathrm{~s}$ at $60^{\circ} \mathrm{C}$. Each PCR reaction was carried out in duplicate. Ubiquitin (ub52) and $\beta$-actin (actb2), which did not vary significantly between samples were used as reference

genes [26]. Relative mRNA expression in samples was determined using the $2^{-(\Delta \Delta C t)}$ method. Clustering analysis was carried out using PermutMatrix [27] as previously described in $[21,22]$.

\subsection{Enzymatic assays}

The Nanno-Y, Nanno-MAe, Nanno-SW, CN-Y, CN-MAe and CN-SW post-larvae collected at 6 and $24 \mathrm{~h}(\mathrm{n}=6$ /group) were weighed and homogenized individually in $500 \mu \mathrm{L}$ of extraction buffer $(1 \mathrm{M}$ Tris- $\mathrm{HCl}, 0.01 \mathrm{M} \mathrm{NaCl}, 0.01 \mathrm{M} \mathrm{KCl}, 0.005 \mathrm{M}$ of $\mathrm{MgCl}_{2}$ ), following the method described in [28]. Lysozyme and total anti-protease activities were measured using a turbidimetric assay [29] and a spectrophotometric method [30] modified by Hanif et al. [31], respectively. Data obtained from the enzymatic assays were expressed as $U$ per post-larvae for lysozyme specific activity and percent total antiprotease activity per post-larvae calculated relative to the positive control (trypsin), which was designated as 100\%. All the measurements were carried out using a microplate reader (BioTek Synergy 4, BioTek Instruments, Inc., USA).

\subsection{Quantification of viral DNA copies}

Determination of viral DNA copies in LCDV-challenged post-larvae $(n=6)$ at 3 and $6 \mathrm{~h}$ and in the LCDV-enriched and control artemia $(\mathrm{n}=6$, treatment vehicle) was established by extracting total DNA using an Isolate II Genomic DNA Kit (Bioline). In the case of LCDV-challenged post-larvae at $24 \mathrm{~h}$, DNA was isolated from the 
organic phase of the TRIsure resulting from the RNA extraction protocol (see section 2.4). In both cases, samples were treated with RNase A (Bioline) following the manufacturer's instructions. DNA was quantified spectrophotometrically using a Nanodrop ND-8000. Absolute quantification of viral DNA copies was carried out according to the protocol specified by Valverde, et al. [24] using a CFX96 ${ }^{\mathrm{TM}}$ RealTime System (Bio-Rad) in a $10 \mu \mathrm{l}$ final volume containing $200 \mathrm{ng}$ of DNA, $300 \mathrm{nM}$ each of the specific forward and reverse primers, and $5 \mu$ of SsoAdvanced ${ }^{\mathrm{TM}}$ Universal SYBR ${ }^{\circledR}$ Green Supermix (Bio-Rad). The amplification protocol used was as follows: 7 min denaturation and enzyme activation at $95^{\circ} \mathrm{C}$, followed by 40 cycles of $30 \mathrm{~s}$ at $95^{\circ} \mathrm{C}$ and $1 \mathrm{~min}$ at $59^{\circ} \mathrm{C}$.

\subsection{Statistical analysis}

Weight and length of sole were compared using a Student t-test. Mortality curves after the administration of bioactive compounds (MAe and Y) were analysed using a Log Rank test. The qPCR data were log-transformed in order to comply with normality and homogeneity of variance. To assess if there were statistical differences in gene expression and enzymatic analysis after bioactive treatments, a General Linear Model (GLM) analysis was used with programming (Nanno or CN), bioactive treatment (Y, MAe or SW), and time $(6,24$ or 48 when available) as fixed factors. To identify significant differences after the LCDV challenge, a GLM analysis was carried out using programming treatment, bioactive treatment and LCDV challenge (V and SWC) as fixed factors. When significant interactions between factors were detected, a twoway or one-way ANOVA was carried out followed by an LSD post-hoc test. 
For viral quantification, a two-way ANOVA was carried out using programming, bioactive treatment or time as fixed factors. When a significant effect was identified, an LSD post-hoc test was carried out. Statistical analyses were performed using SPSS $v 21$ software (IBM) with statistical significance set at $\mathrm{P}<0.05$ and data are presented as mean \pm standard error of the mean (SEM). Principal component analysis (PCA) was performed in FactoMineR [32].

\section{Results}

\subsection{Long-term effects of larval programming on growth}

Treatment of recently hatched larvae with Nanno whole-cell crude extracts for $2 \mathrm{~h}$ did not cause any mortality. After Nanno treatment larvae were reared until the completion of metamorphosis following a standard rearing protocol in the hatcheries and they had a significantly higher dry weight $(1.58 \pm 0.21$ vs $1.16 \pm 0.08 \mathrm{mg})$ and standard length $(0.84 \pm 0.01$ vs $0.70 \pm 0.03 \mathrm{~cm})$ than the $\mathrm{CN}$ group at $21 \mathrm{dph}(P<0.05)$. At 30 dph differences in dry weight were still observable but high data variability meant that no significant differences were found (Fig. 2). However, the wet weight of 32 dph post-larvae treated with Nanno was significantly higher than the CN group, $13.43 \pm 0.19$ vs $12.36 \pm 0.61$, respectively $(P<0.05)$.

\subsection{Survival associated with larval programming after administration of bioactive treatments in post-larvae}

Survival of Nanno and CN sole treated with bioactive treatments (Y or MAe) at 32 dph was monitored over $48 \mathrm{~h}$ and compared with the negative control (SW) (Fig. 3a). Survival was $100 \%$ in all experimental groups (Nanno-Y, Nanno-MAe, Nanno-SW, CN-Y, CN-MAe, CN-SW) 6h after feeding, although a significant increase $(P<0.05)$ 
in mortality occurred from 24 to $48 \mathrm{~h}$ associated with bioactive treatments ( $\mathrm{SW}<\mathrm{Y}<$ $\mathrm{MAe})$ and also between the programming groups $(\mathrm{CN}<\mathrm{Nanno})$.

Cumulative mortality in the CN-SW and Nanno-SW at $48 \mathrm{~h}$ was 0 and $1.0 \pm 1.2 \%$, respectively (Fig. 3a). In the group given Y-enriched artemia, a small increase in mortality occurred in the Nanno-Y group at $24 \mathrm{~h}(2.7 \pm 3.2 \%)$. The cumulative mortality at $48 \mathrm{~h}$ for the $\mathrm{CN}-\mathrm{Y}$ and Nanno-Y groups was $1.8 \pm 2.8 \%$ and $16.7 \pm 13.4 \%$, respectively (Fig. 3a). The highest mortality rates were observed in larvae supplied with MAe enriched artemia. At $24 \mathrm{~h}$, the mortality was $18.6 \pm 16.3 \%$ for the CN-MAe and $96.6 \pm 2.6 \%$ for the Nanno-MAe groups and reached $56.7 \pm 9.9 \%$ and $100 \%$, respectively by $48 \mathrm{~h}$.

\subsection{Enzymatic activities associated with larval programming and the administration of bioactive treatments in post-larvae}

Lysozyme and total anti-protease activities were measured at 6 and $24 \mathrm{~h}$ using whole post-larvae homogenates. Due to the high mortality in the CN-MAe and Nanno-MAe groups, there was not enough specimens for enzymatic analysis at $24 \mathrm{~h}$. Lysozyme but not total antiprotease activities (Fig. 4A and 4B) decreased significantly $(P<0.05)$ with time. With respect to programming, Nanno-treated post-larvae had significantly higher lysozyme $(6 \mathrm{~h})$ and antiprotease $(24 \mathrm{~h})$ activities than the $\mathrm{CN}$ group. When bioactive treatments were compared, a significantly higher lysozyme activity in Nanno-MAe and anti-protease activity in CN-MAe exposed post-larvae compared to control groups (Nanno-SW and CN-SW, respectively) at $6 \mathrm{~h}$ were found.

3.4 Expression profiles associated with larval programming and the administration of bioactive treatments in post-larvae 
To evaluate the long-term effects on the immune response of programming treatment in recently hatched larvae, expression levels of nine genes after administering MAe and $\mathrm{Y}$ through the diet to $32 \mathrm{dph}$ Nanno and $\mathrm{CN}$ post-larvae were quantified. The genes analysed included a) pro-inflammatory genes, illb and tnfa, receptor lectin type-c (clec), chemokine $\operatorname{cxc10,b)}$ antiviral genes irf3, irf7 and $m x$ and c) lymphocyte markers $c d 4$ and $c d 8 a$ (Fig. 5a). The expression levels of most of the genes analysed (except $i l l b$ ) were significantly modified between sampling time points (6 vs 24h). When the programming effect was analysed using GLM, the steady-state gene expression levels of $i l 1 b, c x c 10$ and $m x$ were significantly different between $\mathrm{CN}$ and Nanno groups. The Nanno-MAe and Nanno-Y had higher cxc10 mRNA levels (2.0-fold) than the corresponding $\mathrm{CN}$ groups. For illb and $m x$, a significant interaction occurred between time $\times$ programming at $24 \mathrm{~h}$ and $\mathrm{illb}$ transcripts were 2.3-fold lower and $m x$ mRNAs 1.5-fold higher in Nanno compared to $\mathrm{CN}$. No specific interactions were found between timexprogramming for the other genes analysed.

With respect to the specific immune responses associated with the bioactive treatments, the main effect after GLM analysis was observed for $i l l b$ that had higher mRNA levels in MAe than in Y and SW groups $(P<0.05)($ Fig. 5). These differences were highest at $24 \mathrm{~h}$ (average 2.3-fold higher than the SW). For most of the genes, a significant interaction between time×bioactive treatment was detected in GLM, which is indicative of a time course response triggered by these compounds. Compared to the SW control at $6 \mathrm{~h}$, tnfa, cxc10, irf7 and $m x$ mRNAs increased in postlarvae supplied with MAe and only tnfa increased in those supplied with Y. After an initial rapid stimulation, tnfa, irf3, irf7 and $m x$ mRNAs in MAe and Y groups and $\operatorname{cxc} 10$ levels in MAe decreased at 24h and were lower than the SW control. 


\subsection{Viral loads of post-larvae challenged with LCDV}

Two daysafterthe bioactive treatments'sole post-larvae from the Nanno-Y, NannoSW, CN-Y and CN-SW groups were challenged with LCDV. The final concentration of the virus used to enrich the artemia via the seawater was $5 \times 10^{4} \mathrm{TCID}_{50} \mathrm{~mL}^{-1}$ and resulted in $5.3 \pm 3.0 \times 10^{5} \mathrm{mcp}$ copies $\mu \mathrm{g}$ metanauplii ${ }^{-1}$. No virus was amplified by PCR in the post-larvae from the control group (SWC). Viral mcp DNA was detected in all post-larvae at 3 and $6 \mathrm{~h}$ post-viral challenge (pvc). However, the rates of LCDV positive animals fell at $24 \mathrm{~h}$ pvc and ranged from 50 to $83 \%$ in the CN_SW and CN_Y groups, respectively. No significant differences in the number of viral DNA copies existed between programming or bioactive treatments (GLM; $P>0.05$ ). Significant differences in viral copy number only occurred across time $(P<0.05)$ since they fell from an average of 37 viral $m c p$ copies $\mu \mathrm{gNA}^{-1}$ at $3 \mathrm{~h}$ pvc to 27 copies at $24 \mathrm{~h} \mathrm{pvc} \mathrm{(Fig.} \mathrm{6).}$

\subsection{Gene expression profiles of programmed and bioactive exposed post-larvae after LCDV challenge}

In order to evaluate the immune response in programmed larvae (Nanno and $\mathrm{CN}$ groups) supplied with bioactive treatments (SW and Y groups) and challenged with LCDV the expression patterns of the genes indicated in 3.4 were analysed at $24 \mathrm{~h}$ after challenge. Clustering analysis of gene expression data clearly separated the LCDV-challenged fish from the SWC group (Fig. 7A). Activation of antiviral genes, proinflammatory cytokines and lymphocyte markers was clear and more intense in post-larvae of the Y group (Fig. 7A). Moreover, a Nanno-SW specific gene cluster in the LCDV-infected group was identified. In non-challenged fish (SWC), two major branches separating $\mathrm{SW}$ and $\mathrm{Y}$ irrespective of the programming treatment were 
identified. These differences were also observed in the PCA analysis that clearly separated the LCDV-challenged from the SWC group (Fig 7B and C) and the SW and Y specimens within them.

A detailed analysis of gene expression profiles (Fig. 7A; Suppl. File 1 and 2) indicated that viral challenge triggered a wider and more intense response of cytokines $i l 1 b$ and tnfa, chemokine $c x c 10$, receptor $c l e c$ and the lymphocyte markers $c d 4$ and $c d 8 a$ in the $\mathrm{Y}$ groups compared to the SW groups. However, an interaction between mRNA levels associated with programming and bioactive treatment in the SWC and V-challenged groups was found. In the non-challenged SWC group, GLM indicated that the steady-state mRNA levels of the three antiviral genes (irf7, irf3 and $m x$ ) were higher in Nanno-SW than Nanno-Y. Moreover, in the V-challenged group, no differences in the expression patterns between Nanno-Y and $\mathrm{CN}-\mathrm{Y}$ groups were observed. However, viral challenge activated the expression of antiviral genes higher in the Nanno-SW than CN-SW group without modifying the expression of $i l l b$ in the Nanno-SW group.

\section{Discussion}

There is increasing evidence that fish larvae have high genome plasticity as an adaptive mechanism to variable environmental conditions. Previous studies have demonstrated that small changes in the ambient temperature at which eggs and larvae develop can have persistent effects on myogenesis and somatic growth [33], the stress response [34] and sex differentiation [35]. More recently, non-specific immune memory, or trained immunity, has been demonstrated in fish [7, 36, 37]. This early training of immunity has been proposed as a strategy to manipulate the immune 
response to improve larval rearing performance with benefits for immunity in adults [38]. Previous data in sole pinpointed the window of time at which thermal sensitive imprinting of sole was most effective, namely, the release of larvae from the egg chorion $[10,11]$. The present study demonstrates for the first time that short-term exposure of recently hatched sole larvae to crude extracts of $N$. gaditana has longterm effects on both growth and the immune responses. Nanno-programmed postlarvae were bigger at 21 and $32 \mathrm{dph}$ than untreated controls This change in growth performance has previously been associated with changes in muscle cellularity [33, 39] and a shift in energy pathways due to metabolic programming that in turn modifies appetite and the immune response [7, 40]. The data obtained in this study open-up new potential applications of microalgae not explored until now that could benefit the aquaculture industry.

Previous data from our group demonstrated that yeast $\beta$-glucans and MAe modulate immune system responses in juvenile sole. Oral administration of yeast $\beta$-glucans acted locally in the gut and modulated the immune response and the microbiome, while MAe activated a systemic anti-inflammatory response [13]. In contrast, intraperitoneal injections of MAe provoked a sustained and potent inflammatory response [12]. The higher mortality observed in post-larvae supplied with yeast $\beta$ glucans and MAe confirmed their bioactivity and their action on metabolism and the immune response in fish. These effects are supported by the enhanced growth performance of sole post-larvae and their modified response to the immunomodulatory effects of $\mathrm{Y}$ and MAe bioactive treatments compared to the SW group. 
Lysozyme and antiprotease activities represent two elements of the innate defence against bacteria. An increase in serum lysozyme levels and antiprotease activities in response to bacterial infections or after the administration of immunostimulants has been associated with enhanced disease resistance [41, 42]. Hence, these enzymes are frequently monitored as health markers and are highly modulated by nutrition, stress, infection, pollution [41] and by thermal imprinting in zebrafish [43]. In our study, higher levels of lysozyme and antiprotease activities were detected in Nanno-programmed larvae indicating that our microalgal crude extracts had long-term effects on the enhancement of innate immunity. Moreover, it should be noted that MAe (6h after exposure) increased the activity of these enzymes corroborating the results of previous studies indicating the high potential of this extract as an immunomodulator $[12,13]$. The decreased activity of lysozyme observed at $24 \mathrm{~h}$ may be due to the acute stress associated with the high mortality observed, since stressful situations are known to reduce humoral defences and lysozyme levels [44].

The Nanno programming treatments enhanced the mRNA levels of chemokine cxc10 and the antiviral (irf3, irf7, and $m x$ ) immune transcripts in post-larvae, indicating a heightened response of antiviral genes to the LCDV challenge and a reduction in proinflammatory cytokines. The elevated levels of antiviral immune transcripts in fish is a well conserved mechanism to provide rapid protection against lethal virus infections in the aquatic environment [37]. It is well-established that $\beta$-glucans, and particularly soluble laminarin, are major inducers of trained immunity in fish and cause increased phagocytosis and expression of inflammatory cytokines and viral resistance [7, 45]. Since a crude Nanno extract was used in this study it was not possible to associate a specific microalgal molecule to the programming of antiviral defences and 
proinflammatory cytokines. Nonetheless, the approach used represents a novel and promising approach with potential for the control microbial diseases in fish.

Dietary supply or injection of $\beta$-glucans increase the expression and production of pro-inflammatory cytokines and stimulates phagocytic, cytotoxic, and antimicrobial activities although with some differences depending on the $\beta$-glucan structure and solubility $[3,6]$. In this study, we demonstrated that both MAe and yeast $\beta$-glucans modified the steady-state levels of innate immune genes as well as the intensity of the defensive response to LCDV. The administration of both bioactive compounds activated a quick and transient immunomodulatory response that was more intense in MAe treatments. This heightened response observed for MAe supports the more systemic action of this soluble extract than particulate yeast $\beta$-glucans as suggested in Carballo, et al. [13] and the strong induction of pro-inflammatory cytokines and other innate immune related genes when injected i.p. in juveniles [12]. It should be noted that the response to $\mathrm{Y}$ and MAe exposure or LCDV challenge was dynamic and postlarvae reduced gene expression levels progressively after the treatments. Interestingly, comparison of gene expression levels between SW and Y in the SWC group revealed long-lasting changes at 96h (Fig. 7). The down-regulation of cytokines and antiviral genes after $\beta$-glucan exposure is reminiscent of the homeostatic mechanism that balances harmful and defensive inflammatory responses stimulated by pathogens [46, 47].

The LCDV challenge triggered a broad defensive response and activated the expression of most of the genes investigated. The quick and systemic antiviral defensive response that involved several antiviral pathways, cellular markers and inflammation-related genes has previously been related to the high resistance of sole 
to LCDV $[21,22]$ and other fish viruses $[45,48]$. Reduction in $m c p$ copies has been associated with the capacity of the immune response to block viral replication and spreading [22]. Interestingly, the clustering and PCA analysis clearly demonstrated an interaction between Nanno-programming and yeast $\beta$-glucan treatments that affected mainly the antiviral genes (irf7, $\operatorname{irf} 3$ and $m x$ ) and pro-inflammatory cytokines $i l l b$ and tnfa. No differences in response to LCDV were found between programming treatments in Y-supplied post-larvae. In contrast, the Nanno-programmed fish of the SW group activated higher expression of antiviral genes and did not modify expression of pro-inflammatory cytokines compared to $\mathrm{CN}$ post-larvae. Previous studies have demonstrated that the innate immune system can be trained, through epigenetic modifications, towards a specific response depending on the molecule used to prime the innate immune system [49]. Our results demonstrate that the Nanno extracts produced long-term effects on the steady-state level and response of antiviral genes to LCDV. Further research is necessary to identify the molecules in microalgal extracts responsible for the effects identified and how they modified the response of post-larvae sole to $\beta$-glucans.

In summary, this study demonstrated that a crude extract of $N$. gaditana can be used for larval programming in sole and that the effect lasts into the post-larvae stage. The methodology developed using larvae at hatch was technically simple and can readily be applied in hatcheries and represents a new potential application for microalgae not explored until now. The better growth performance and the enhancement of the immune response after supplying bioactive treatments or challenging with LCDV indicates they have the potential to improve operational methods used in fish hatcheries for management and disease control. The interaction between $\beta$-glucans 
and Nanno programming after the LCDV challenge suggests that they mediate their actions via different regulatory pathways and this aspect deserves to be further investigated.

\section{Funding}

This study was funded by H2020 MSCA-RISE project 691102 (Algae4A\&B), IFAPA project RTA2017-00054-C03-01 funded from MCIU/AEI/FEDER, UE and a CCMAR program grant from the Foundation for Science and Technology (Portugal, UIDB/04326/2020) and the operational programmes CRESC Algarve 2020 and COMPETE 2020 (EMBRC.PT ALG-01-0145-FEDER-022121). CC is funded by a predoctoral fellowship from INIA.

\section{Conflict of Interests}

The authors declare they have no conflict of interests.

\section{Authors'contributions}

$\mathrm{CC}$ : Investigation for gene expression and viral analysis, fish laboratory experiments, gene expression and viral analysis. sampling, data Curation, validation of results, sampling; APM: Investigation for enzymatic activities, Data Curation; CM: Resources. Microalgal MAe extract; LM: Resources. Microalgal extracts. Supervision, Funding acquisition; DMP Conceptualization, Supervision, Funding acquisition, Writing - Review \& Editing; MM: Conceptualization, Supervision, Funding acquisition, Writing - Original Draft, Review \& Editing. 


\section{Captions}

Figure 1. A) Experimental design for bioactive treatment. Nanno-programmed (Nanno) and negative control sole post-larvae $(\mathrm{CN})$ were distributed in trays $(n=80)$ and given artemia that was enriched for 30 min with bioactive treatments (Microalgal extract (MAe) or yeast $\beta$-glucans (Y)) or seawater (SW) as a control group in triplicate (x3). A second dose was also supplied $4 \mathrm{~h}$ after the onset of the bioactive trial and the post-larvae were sampled at 6 and $24 \mathrm{~h}$ (in blue). After $48 \mathrm{~h}$, post-larvae from SW and Y groups (that also contained the $\mathrm{CN}$ and Nanno groups) were distributed in new trays ( $n=30 /$ tray) in duplicate and challenged with artemia infected with the virus LCDV. Post-larvae fed artemia enriched with clean seawater (SWC) was used as a negative control. Samplings were carried out at 3, 6 and $24 \mathrm{~h}$ after the LCDV challenge. B) Codes used in the study to identify the experimental groups

Figure 2. Dry weight (A) and length (B) of programming treatments (CN and Nanno). Asterisks denote the existence of statistically significant differences among treatments $(P<0.05)$.

Figure 3. Cumulative mortality (\%) of $\mathrm{CN}$ and Nanno-programmed (Nanno) postlarvae administrated the bioactive treatments (MAe in the dashed green line and $\mathrm{Y}$ in the orange line) and the negative control (SW). The control groups are indicated with square symbol and Nanno post-larvae with circular symbols. Mortality were recorded for $48 \mathrm{~h}$ after the onset of the trial. 
Figure 4. A) Lysozyme and B) antiprotease enzymatic activities of $\mathrm{CN}$ and Nanno post-larvae administrated the bioactive treatments (MAe and $\mathrm{Y}$ ) and the negative control (SW). Enzyme activity was measured in homogenates of post-larvae sampled at 6 and $24 \mathrm{~h}$ after the onset of the trial. The mean \pm SEM are represented and expressed as $\mathrm{U}$ per post-larvae for lysozyme (A) and \% inhibition per post-larvae for anti-protease (B) activity. Letters denote significant differences between bioactive treatments at a specific time point for the $\mathrm{CN}$ and Nanno (letters added ') groups. Asterisks indicate significant differences between programming treatments at the same time point and the symbol "\&" between time points. Significance was set at $P<0.05$.

Figure 5. Relative gene expression levels of $\mathrm{CN}$ and Nanno-programmed post-larvae treated with the bioactives, MAe and $\mathrm{Y}$ and the negative control (SW). Expression levels were determined at 6 and $24 \mathrm{~h}$ after the onset of the trial. The control group $(\mathrm{SW})$ is indicated by blue bars, MAe in green bars and $\mathrm{Y}$ in orange bars. Data are expressed as the mean \pm SEM, $\mathrm{n}=4$, the calibrator group is the $\mathrm{SW}$ control 6h). Significant differences for programming (Progr), bioactive treatments (Bio $\mathrm{T}$ ) and time are indicated in the square. The post-hoc result is indicated on the right if significant. Interactions are only shown when significant. When interactions are significant, a two-way analysis was carried out. In this case, letters denote significant differences between bioactive treatments at the same time point ( $6 \mathrm{~h}$ in lowercase and $24 \mathrm{~h}$ in uppercase). Post-hoc analysis is indicated in letters using the colour code indicated above. Asterisks indicate significant differences between programming treatments at the same time point. Significance was set at $\mathrm{P}<0.05$. 
Figure 6. Quantification of LCDV genomic DNA in infected Senegalese sole postlarvae at 3, 6 and $24 \mathrm{~h}$ post-challenge (pch). LCDV DNA copies in CN (grey) and Nanno (green) are indicated. Data are expressed as the mean logarithm of viral DNA copies per $\mu \mathrm{g}$ of total DNA \pm SEM. Letters denote the significant differences between sampling points $(P<0.05)$.

Figure 7. Hierarchical heat map cluster (A) and Principal components analysis (PCA) (B and C) using the gene expression values at $24 \mathrm{~h}$ after a LCDV challenge. A) Data were normalized using $\log 2$ of fold-change. Green and red colours indicate low and high expression values, respectively according to the scale shown. Sample codes are as follows: first Letter $\mathrm{CN}$ or Nanno indicates if control or Nanno programmed; second letter indicates if post-larvae were administrated MAe, $\mathrm{Y}$ or SW; the third letter if post-larvae were challenged with $\operatorname{LCDV}(\mathrm{V})$ or the negative control (SWC). The main clusters grouping the LCDV (red) and SWC (green) as well as other subclusters grouping similar samples are indicated. Gene names are shown on the left. B) and C) Principal Component Analysis (PCA) plot based on the complete set of genes analyzed representing the samples $(n=4)$ for programming $(B)$ or bioactive $(C)$ treatments. The confidence ellipses (95\%) for LCDV challenge groups (SWC and V) are indicated. Dimension 1 explains $48.6 \%$ and dimension 2 the $20.5 \%$ of total variation.

\section{Supplementary files}

Suppl. file 1 Relative gene expression levels of the control (CN; grey) and Nannoprogrammed (Nanno; green) post-larvae administrated Y (solid color) or SW (crosshatched color). V indicates the infected and SWC the non-infected groups. Expression 
levels were determined at $24 \mathrm{~h}$ after the challenge. Data are expressed as mean \pm SEM, $\mathrm{n}=4$ from the calibrator group (CN-SW-SWC group). Significant effects of programming (Prog), bioactive treatments (Bio T) and LCDV infection (challg) and post-hoc comparisons are shown. When the interaction was significant, a two-way ANOVA was carried out. In this case, letters indicate significant differences between programming groups for each bioactive treatment. Asterisks denote significant differences between viral treatments for each bioactive treatment. Letters above the colour squares and the hash sign denotes significant differences between groups. Significant differences were set at $P<0.05$

Suppl file 2. The principal component analysis (PCA) biplot of the gene set analysed in samples for programming (A), bioactive compounds (B) and virus challenge (C). The name of the genes is indicated in the arrows. The confidence ellipses $(95 \%)$ for each experimental group are shown.

\section{References}

[1] N. Akhter, B. Wu, A.M. Memon, M. Mohsin, Probiotics and prebiotics associated with aquaculture: A review, Fish Shellfish Immunol 45(2) (2015) 733-41. https://doi.org/10.1016/j.fsi.2015.05.038

[2] S.K. Song, B.R. Beck, D. Kim, J. Park, J. Kim, H.D. Kim, E. Ringo, Prebiotics as immunostimulants in aquaculture: a review, Fish Shellfish Immunol 40(1) (2014) 40-8. https://doi.org/10.1016/j.fsi.2014.06.016

[3] D.K. Meena, P. Das, S. Kumar, S.C. Mandal, A.K. Prusty, S.K. Singh, M.S. Akhtar, B.K. Behera, K. Kumar, A.K. Pal, S.C. Mukherjee, Beta-glucan: an ideal immunostimulant in aquaculture (a review), Fish Physiol Biochem 39(3) (2013) 431-57. https://doi.org/10.1007/s10695-012-9710-5

[4] L. Barsanti, V. Passarelli, V. Evangelista, A.M. Frassanito, P. Gualtieri, Chemistry, 
physico-chemistry and applications linked to biological activities of beta-glucans, Nat Prod Rep 28(3) (2011) 457-66. https://doi.org/10.1039/c0np00018c

[5] I. Noss, G. Doekes, P.S. Thorne, D.J. Heederik, I.M. Wouters, Comparison of the potency of a variety of beta-glucans to induce cytokine production in human whole blood, Innate Immun 19(1) (2013) 10-9. https://doi.org/10.1177/1753425912447129

[6] V. Vetvicka, L. Vannucci, P. Sima, The effects of beta-glucan on fish immunity, N Am J Med Sci 5(10) (2013) 580-8. https://doi.org/10.4103/1947-2714.120792

[7] J. Petit, C.W.E. Embregts, M. Forlenza, G.F. Wiegertjes, Evidence of trained immunity in a fish: conserved features in carp macrophages, J Immunol 203(1) (2019) 216-224. https://doi.org/10.4049/jimmunol.1900137

[8] Z. Zhang, H. Chi, R.A. Dalmo, Trained innate immunity of fish is a viable approach in larval aquaculture, Front Immunol 10 (2019) 42. https://doi.org/10.3389/fimmu.2019.00042

[9] C. van der Heijden, M.P. Noz, L.A.B. Joosten, M.G. Netea, N.P. Riksen, S.T. Keating, Epigenetics and trained immunity, Antioxid Redox Signal 29(11) (2018) 1023-1040. https://doi.org/10.1089/ars.2017.7310

[10] C. Carballo, J. Firmino, L. Anjos, S. Santos, D.M. Power, M. Manchado, Short- and long-term effects on growth and expression patterns in response to incubation temperatures in $\begin{array}{lllll}\text { Senegalese } & \text { sole, } & \text { Aquaculture } & 495 & \text { (2018) }\end{array}$ https://doi.org/10.1016/j.aquaculture.2018.05.043

[11] J. Firmino, C. Carballo, P. Armesto, M.A. Campinho, D.M. Power, M. Manchado, Phylogeny, expression patterns and regulation of DNA Methyltransferases in early development of the flatfish, Solea senegalensis, BMC Dev Biol 17(1) (2017) 11. https://doi.org/10.1186/s12861-017-0154-0

[12] C. Carballo, E.G. Chronopoulou, S. Letsiou, C. Maya, N.E. Labrou, C. Infante, D.M. Power, M. Manchado, Antioxidant capacity and immunomodulatory effects of a chrysolaminarin-enriched extract in Senegalese sole, Fish Shellfish Immunol 82 (2018) 1-8. https://doi.org/10.1016/j.fsi.2018.07.052

[13] C. Carballo, P.I.S. Pinto, A.P. Mateus, C. Berbel, C.C. Guerreiro, J.F. Martinez-Blanch, F.M. Codoner, L. Mantecon, D.M. Power, M. Manchado, Yeast beta-glucans and microalgal extracts modulate the immune response and gut microbiome in Senegalese sole (Solea senegalensis), Fish Shellfish Immunol $92 \quad$ (2019) 31-39. https://doi.org/10.1016/j.fsi.2019.05.044

[14] M. Libran-Perez, M.M. Costa, A. Figueras, B. Novoa, beta-glucan administration induces metabolic changes and differential survival rates after bacterial or viral infection in turbot (Scophthalmus maximus), Fish Shellfish Immunol 82 (2018) 173-182. https://doi.org/10.1016/j.fsi.2018.08.005 
[15] J.J. Borrego, E.J. Valverde, A.M. Labella, D. Castro, Lymphocystis Disease Virus: its importance in aquaculture, Rev Aquacult 9(2) (2017) 179-193. https://doi.org/10.1111/raq.12131

[16] R. Harikrishnan, C. Balasundaram, M.S. Heo, Effect of probiotics enriched diet on Paralichthys olivaceus infected with lymphocystis disease virus (LCDV), Fish Shellfish Immunol 29(5) (2010) 868-74. https://doi.org/10.1016/j.fsi.2010.07.031

[17] R. Harikrishnan, J. Heo, C. Balasundaram, M.C. Kim, J.S. Kim, Y.J. Han, M.S. Heo, Effect of Punica granatum solvent extracts on immune system and disease resistance in Paralichthys olivaceus against lymphocystis disease virus (LDV), Fish Shellfish Immunol 29(4) (2010) 668-73. https://doi.org/10.1016/j.fsi.2010.07.006

[18] M. Ferreira, A. Cortina-Burgueño, I. Freire, A. Otero, Effect of nutritional status and concentration of Nannochloropsis gaditana as enrichment diet for the marine rotifer $\begin{array}{lllll}\text { Brachionus } & \text { sp, } & \text { Aquaculture } & 491 & \text { 351-357. }\end{array}$ https://doi.org/10.1016/j.aquaculture.2018.03.024

[19] S. Letsiou, K. Kalliampakou, K. Gardikis, L. Mantecon, C. Infante, M. Chatzikonstantinou, N.E. Labrou, E. Flemetakis, Skin protective effects of Nannochloropsis gaditana extract on $\mathrm{H}_{2} \mathrm{O}_{2}$-stressed human dermal fibroblasts, Front Mar Sci 4 (2017) 221. https://doi.org/10.3389/fmars.2017.00221

[20] M. Mitra, S.K. Patidar, B. George, F. Shah, S. Mishra, A euryhaline Nannochloropsis gaditana with potential for nutraceutical (EPA) and biodiesel production, Algal Res 8 (2015) 161-167. https://doi.org/10.1016/j.algal.2015.02.006

[21] C. Carballo, D. Castro, J.J. Borrego, M. Manchado, Gene expression profiles associated with lymphocystis disease virus (LCDV) in experimentally infected Senegalese sole (Solea senegalensis), Fish Shellfish Immunol $66 \quad$ (2017) 129-139. https://doi.org/10.1016/j.fsi.2017.04.028

[22] C. Carballo, J.B. Ortiz-Delgado, C. Berbel, D. Castro, J.J. Borrego, C. Sarasquete, M. Manchado, Feed and immersion challenges with lymphocystis disease virus (LCDV) reveals specific mechanisms for horizontal transmission and immune response in Senegalese sole $\begin{array}{llllll}\text { post-larvae, } & \text { Fish } & \text { Shellfish } & \text { Immunol } & 89 & \text { (2019) }\end{array}$ https://doi.org/10.1016/j.fsi.2019.04.049

[23] M.C. Alonso, I. Cano, E. Garcia-Rosado, D. Castro, J. Lamas, J.L. Barja, J.J. Borrego, S.M. Bergmann, Isolation of lymphocystis disease virus from sole, Solea senegalensis Kaup, and blackspot sea bream, Pagellus bogaraveo (Brunnich), J Fish Dis 28(4) (2005) 221-8. https://doi.org/10.1111/j.1365-2761.2005.00621.x

[24] E.J. Valverde, I. Cano, A. Labella, J.J. Borrego, D. Castro, Application of a new realtime polymerase chain reaction assay for surveillance studies of lymphocystis disease virus in 
farmed gilthead seabream, BMC Vet Res 12 (2016) 71. https://doi.org/10.1186/s12917-016$\underline{0696-6}$

[25] A. Fernandez-Trujillo, P. Ferro, E. Garcia-Rosado, C. Infante, M.C. Alonso, J. Bejar, J.J. Borrego, M. Manchado, Poly I:C induces Mx transcription and promotes an antiviral state against sole aquabirnavirus in the flatfish Senegalese sole (Solea senegalensis Kaup), Fish Shellfish Immunol 24(3) (2008) 279-85. https://doi.org/10.1016/j.fsi.2007.11.008

[26] C. Infante, M.P. Matsuoka, E. Asensio, J.P. Cañavate, M. Reith, M. Manchado, Selection of housekeeping genes for gene expression studies in larvae from flatfish using real-time PCR, BMC Mol. Biol. 9 (2008) 28. https://doi.org/10.1186/1471-2199-9-28

[27] G. Caraux, S. Pinloche, PermutMatrix: a graphical environment to arrange gene expression profiles in optimal linear order, Bioinformatics 21(7) (2005) 1280-1. https://doi.org/10.1093/bioinformatics/bti141

[28] G. Sych, P. Frost, I. Irnazarow, Influence of $\beta$-Glucan (MACROGARD®) on innate immunity of carp fry B Vet I Pulawy 52(2) (2013) 219-223. https://doi.org/10.2478/bvip$\underline{2013-0039}$

[29] A.E. Ellis, Lysozyme assays in: J.S. Stolen, F.T. Fletcher, D.P. Anderson, B.S. Roberson (Eds.), Techniques in fish immunology SOS Publications, Fair Haven, NJ, 1990, pp. 101-103.

[30] A.E. Ellis, Serum antiproteases in fish, in: J.S.F. Stolen, F.T.; Anderson, D.P.; Roberson, B.S. (Ed.), Techniques in fish immunology SOS Publications, Fair Haven, NJ, 1990, pp. 9599.

[31] A. Hanif, V. Bakopoulos, G.J. Dimitriadis, Maternal transfer of humoral specific and non-specific immune parameters to sea bream (Sparus aurata) larvae, Fish Shellfish Immunol 17 (2004) 411-35. https://doi.org/10.1016/j.fsi.2004.04.013

[32] S. Lê, J. Josse, F. Husson, FactoMineR: An R Package for Multivariate Analysis, J Stat Soft 25 (2008) 1-18. https://doi.org/10.18637/jss.v025.i01

[33] C. Campos, L.M. Valente, L.E. Conceiçao, S. Engrola, V. Sousa, E. Rocha, J.M. Fernandes, Incubation temperature induces changes in muscle cellularity and gene expression in Senegalese sole (Solea senegalensis), Gene 516(2) (2013) 209-17. https://doi.org/10.1016/j.gene.2012.12.074

[34] A.P. Mateus, R.A. Costa, J.C.R. Cardoso, K.B. Andree, A. Estevez, E. Gisbert, D.M. Power, Thermal imprinting modifies adult stress and innate immune responsiveness in the teleost sea bream, J Endocrinol 233(3) (2017) 381-394. https://doi.org/10.1530/JOE-16-0610 [35] L. Navarro-Martin, J. Vinas, L. Ribas, N. Diaz, A. Gutierrez, L. Di Croce, F. Piferrer, DNA methylation of the gonadal aromatase (cyp19a) promoter is involved in temperaturedependent sex ratio shifts in the European sea bass, PLoS Genet 7(12) (2011) e1002447. https://doi.org/10.1371/journal.pgen.1002447 
[36] J. Petit, G.F. Wiegertjes, Long-lived effects of administering beta-glucans: Indications for trained immunity in fish, Dev Comp Immunol 64 (2016) 93-102. https://doi.org/10.1016/j.dci.2016.03.003

[37] P. Garcia-Valtanen, A. Martinez-Lopez, A. Lopez-Munoz, M. Bello-Perez, R.M. Medina-Gali, M.D. Ortega-Villaizan, M. Varela, A. Figueras, V. Mulero, B. Novoa, A. Estepa, J. Coll, Zebra Fish lacking adaptive immunity acquire an antiviral alert state characterized by ppregulated gene expression of apoptosis, multigene families, and $\begin{array}{llllll}\text { Interferon-telated } & \text { genes, } & \text { Front } & \text { Immunol } & 8 & \text { (2017) }\end{array}$ https://doi.org/10.3389/fimmu.2017.00121

[38] A.H. Rojo-Cebreros, L. Ibarra-Castro, J.M. Martinez-Brown, Immunostimulation and trained immunity in marine fish larvae, Fish Shellfish Immunol 80 (2018) 15-21. https://doi.org/10.1016/j.fsi.2018.05.044

[39] I. Albokhadaim, C.L. Hammond, C. Ashton, B.H. Simbi, S. Bayol, S. Farrington, N. Stickland, Larval programming of post-hatch muscle growth and activity in Atlantic salmon (Salmo salar), J Exp Biol 210(Pt 10) (2007) 1735-41. https://doi.org/10.1242/jeb.003194

[40] L.A. Fuiman, K.O. Perez, Metabolic programming mediated by an essential fatty acid alters body composition and survival skills of a marine fish, Proc Biol Sci 282(1819) (2015). https://doi.org/10.1098/rspb.2015.1414

[41] S. Saurabh, P.K. Sahoo, Lysozyme: an important defence molecule of fish innate immune system, Aquaculture Res 39 (2008) 223-239. https://doi.org/10.1111/j.13652109.2007.01883.x

[42] S.K. Priyadarshini, P.A. Subramani, R.D. Michael, Modulation of the innate immune responses in the striped snakehead murrel, Channa striata upon experimental infection with live and heat killed Aeromonas hydrophila, Open Vet J 7(2) (2017) 157-164. https://doi.org/10.4314/ovj.v7i2.13

[43] Q. Zhang, M. Kopp, I. Babiak, J.M.O. Fernandes, Low incubation temperature during early development negatively affects survival and related innate immune processes in zebrafish larvae exposed to lipopolysaccharide, Sci Rep 8(1) (2018) 4142. https://doi.org/10.1038/s41598-018-22288-8

[44] G. Jeney, M. Galeotti, D. Volpatti, Z. Jeney, D. Anderson, Prevention of stress in rainbow trout (Oncorhynchus mykiss) fed diets containing different doses of glucan, Aquaculture 154 (1997) 1-15. https://doi.org/10.1016/S0044-8486(97)00042-2

[45] R.M. Medina-Gali, M.D.M. Ortega-Villaizan, L. Mercado, B. Novoa, J. Coll, L. Perez, Beta-glucan enhances the response to SVCV infection in zebrafish, Dev Comp Immunol 84 (2018) 307-314. https://doi.org/10.1016/j.dci.2018.02.019

[46] A. Falco, P. Frost, J. Miest, N. Pionnier, I. Irnazarow, D. Hoole, Reduced inflammatory 
response to Aeromonas salmonicida infection in common carp (Cyprinus carpio L.) fed with beta-glucan supplements, Fish Shellfish Immunol 32(6) (2012) 1051-7. https://doi.org/10.1016/j.fsi.2012.02.028

[47] A. Falco, J.J. Miest, N. Pionnier, D. Pietretti, M. Forlenza, G.F. Wiegertjes, D. Hoole, beta-Glucan-supplemented diets increase poly(I:C)-induced gene expression of Mx, possibly via Tlr3-mediated recognition mechanism in common carp (Cyprinus carpio), Fish Shellfish Immunol 36(2) (2014) 494-502. https://doi.org/10.1016/j.fsi.2013.12.005

[48] Y.S. Kim, F. Ke, Q.Y. Zhang, Effect of beta-glucan on activity of antioxidant enzymes and Mx gene expression in virus infected grass carp, Fish Shellfish Immunol 27(2) (2009) 336-40. https://doi.org/10.1016/j.fsi.2009.06.006

[49] S.M. Quinn, K. Cunningham, M. Raverdeau, R.J. Walsh, L. Curham, A. Malara, K.H.G. Mills, Anti-inflammatory trained immunity mediated by helminth products attenuates the induction of $\mathrm{T}$ cell-mediated autoimmune disease, Front Immunol 10 (2019) 1109. https://doi.org/10.3389/fimmu.2019.01109 


\section{Highlights}

Crude extracts of microalga Nannochloropsis gaditana modified larval programming for growth performance in sole post-larvae

Yeast $\beta$-glucan and microalgal extract activated immune gene responses but modulated by larval programming in sole post-larvae

LCDV DNA copies were not modified by programming or bioactive treatments. .

LCDV activated a wide defensive response modulated by yeast $\beta$-glucan and Nannoprogramming 


\section{Credit Author Statement}

$\mathrm{CC}$ : Investigation for gene expression and viral analysis, fish laboratory experiments, gene expression and viral analysis. sampling, data Curation, validation of results, sampling; APM: Investigation for enzymatic activities, Data Curation; CM; Resources. Microalgal MAe extract; LM: Resources. Microalgal extracts. Supervision, Funding acquisition; DMP Conceptualization, Supervision, Funding acquisition, Writing - Review \& Editing; MM: Conceptualization, Supervision, Funding acquisition, Writing - Original Draft, Review \& Editing. 


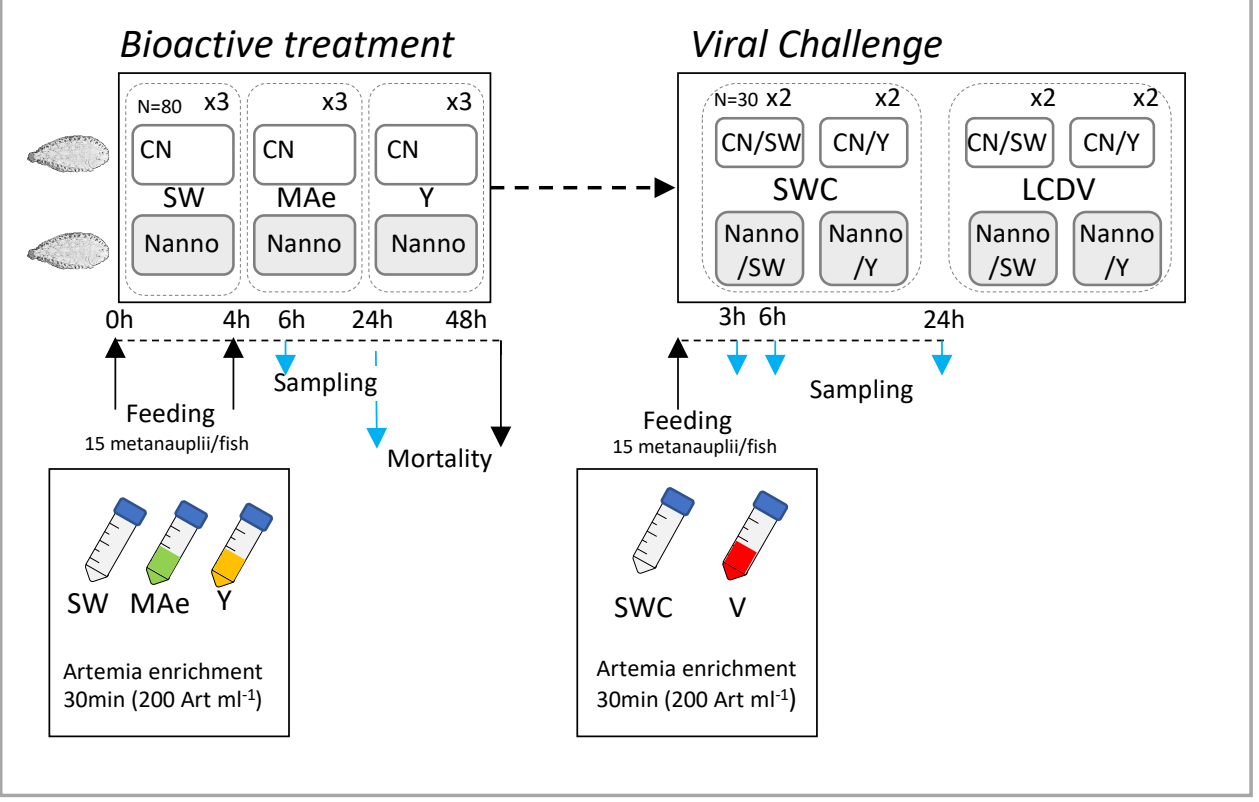

\begin{tabular}{|l|l|l|}
\hline Programming & \multicolumn{2}{|l|}{ Larval exposure at 1 dph } \\
\hline N. gaditana extract & Nanno & \\
\hline Seawater control & CN & \\
\hline $\begin{array}{l}\text { Biotreatment } \\
\text { (BioT) }\end{array}$ & $\begin{array}{l}\text { Post-larvae exposure at 32 dph } \\
\text { (programming*BioT) }\end{array}$ \\
\hline yeast $\beta$-glucan & Nanno-Y & CN-Y \\
\hline $\begin{array}{l}\text { P. tricornutum } \\
\text { Microalgal extract }\end{array}$ & Nanno-MAe & CN-MAe \\
\hline Seawater control & Nanno-SW & CN-SW \\
\hline Challenge & $\begin{array}{l}\text { Post-larvae viral challenge } \\
\text { (programming*BioT*challenge) }\end{array}$ \\
\hline LCDV & $\begin{array}{l}\text { Nanno-Y-V } \\
\text { Nanno-SW-V }\end{array}$ & $\begin{array}{l}\text { CN-Y-V } \\
\text { CN-SW-V }\end{array}$ \\
\hline Seawater control & $\begin{array}{l}\text { Nanno-Y-SWC } \\
\text { Nanno-SW-SWC }\end{array}$ & $\begin{array}{l}\text { CN-Y-SWC } \\
\text { CN-SW-SWC }\end{array}$ \\
\hline
\end{tabular}



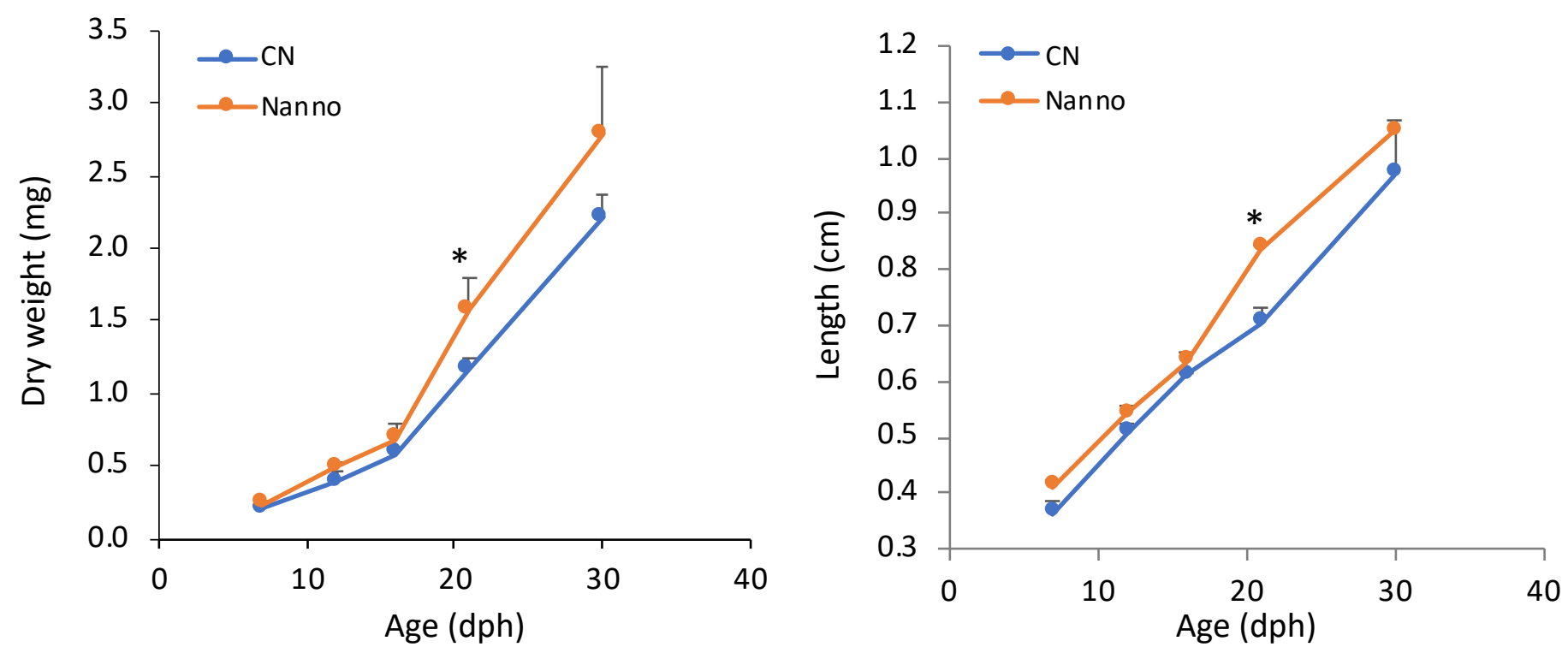


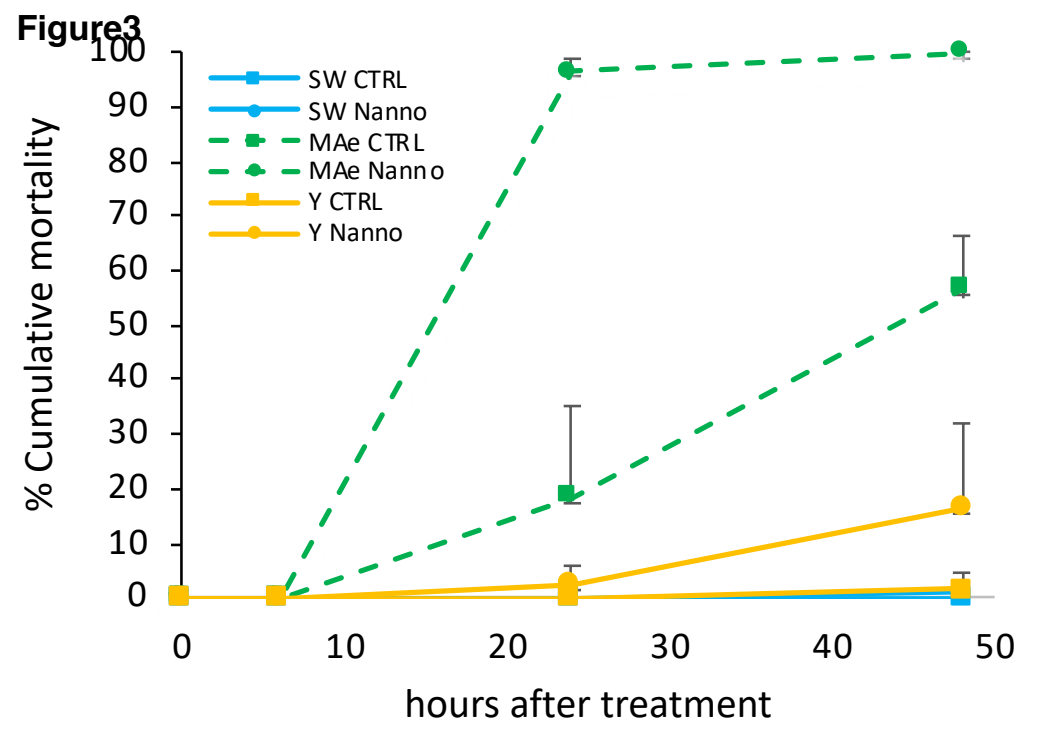


Figure $4_{100}$

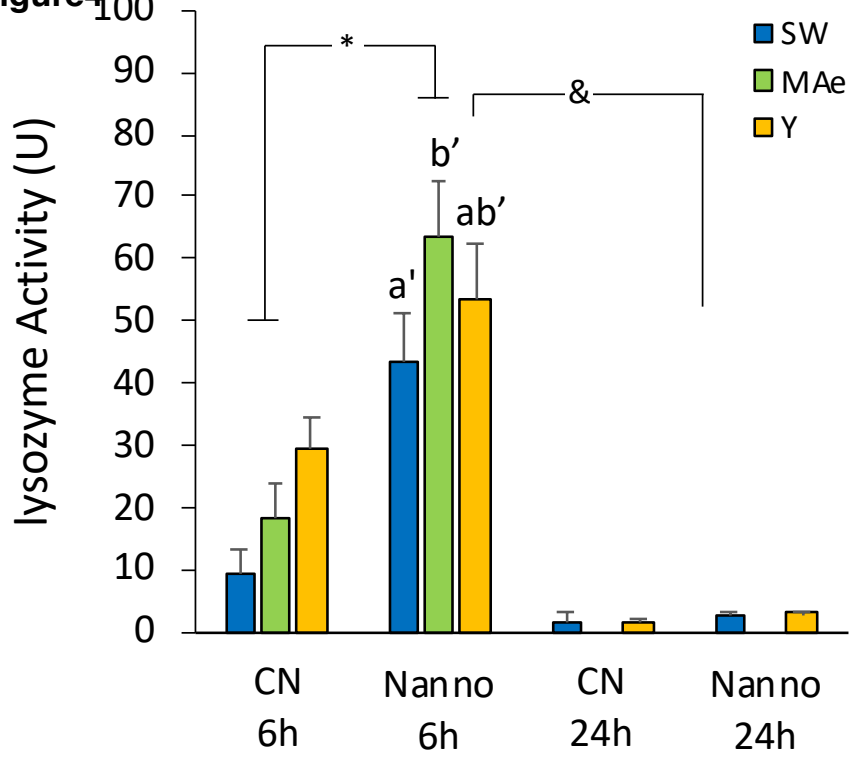

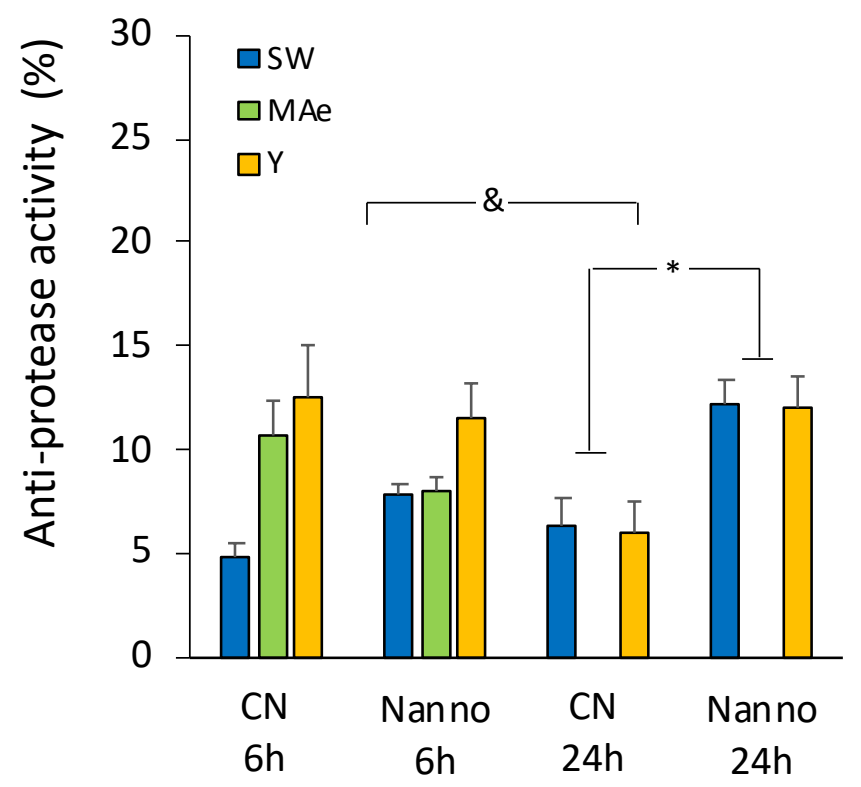


Figure

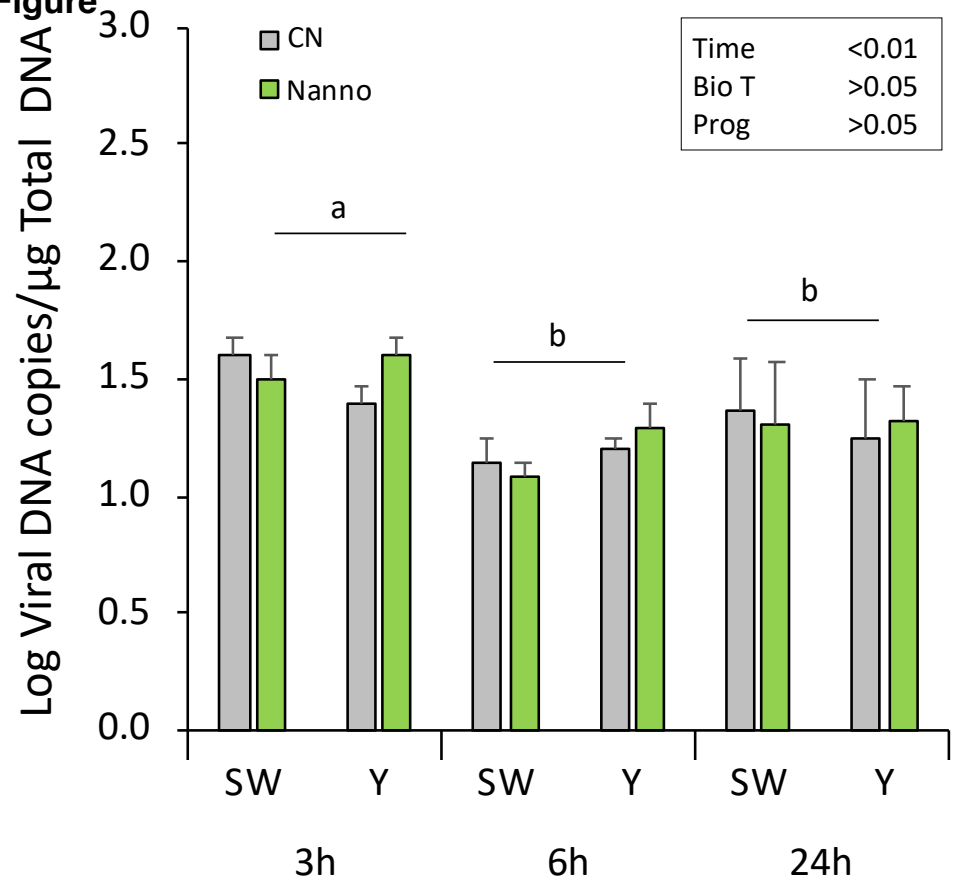




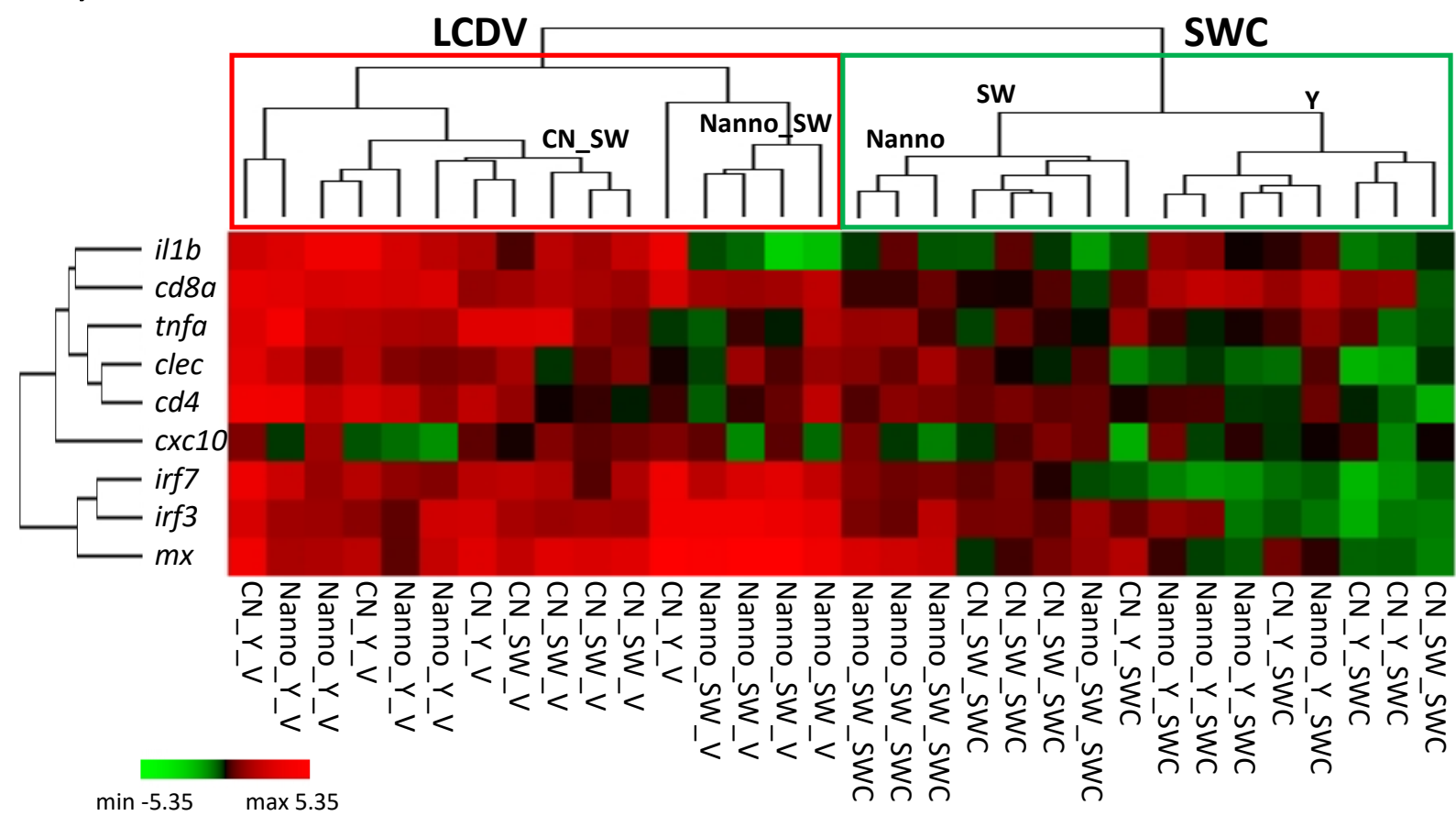

B)

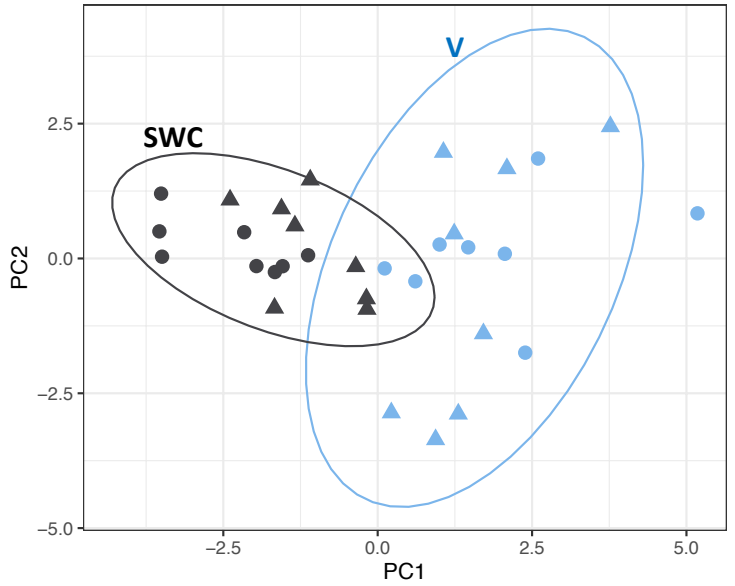

C)

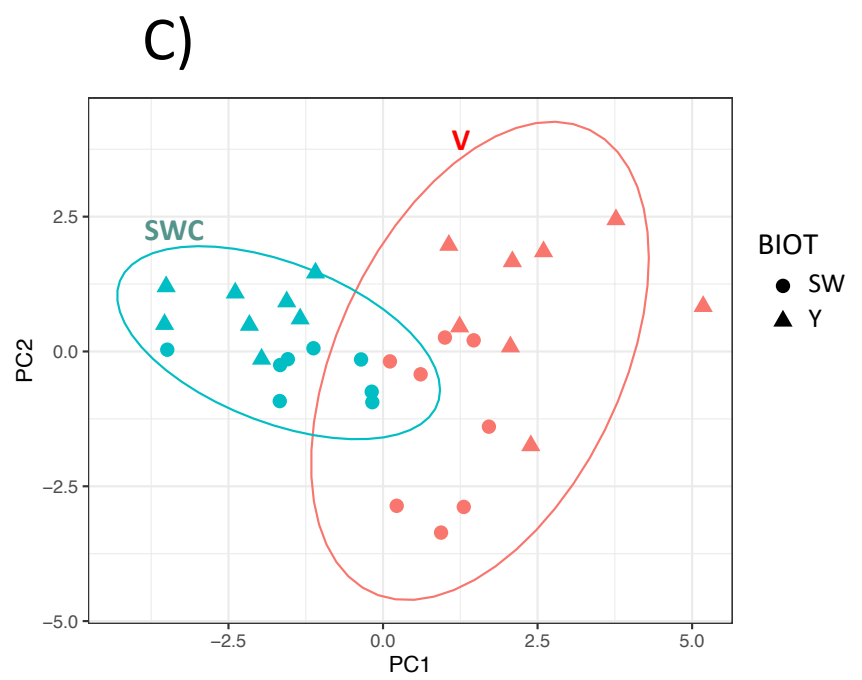

PROGRAM

- CN

A Nanno 

Supplementary material for online publication only
Click here to download Supplementary material for

Click here to download Supplementary material for online publication only: Suppl1.pdf
( (

for online publication only: Suppl1.pdf

(1)

10

.

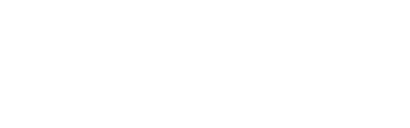

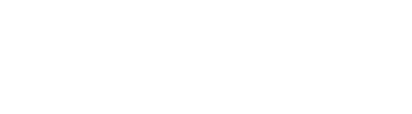

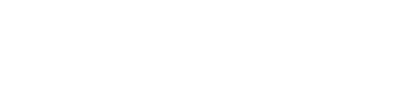
.

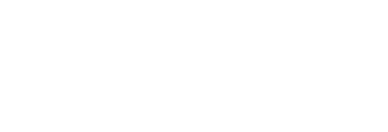
.

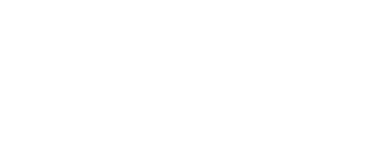

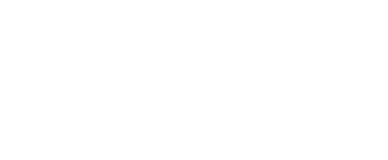

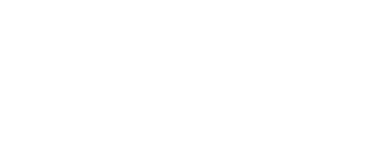

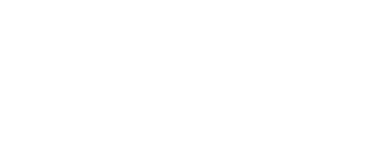

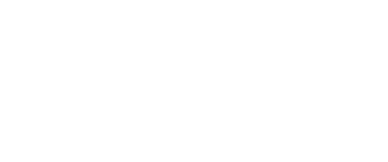

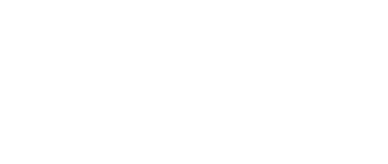

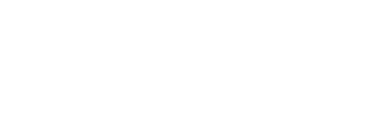



Supplementary material for online publication only
Click here to download Supplementary material for

Supplementary material for online publication only
Click here to download Supplementary material for online publication only: Suppl2.pdf for lick here to download Supplementary material for online publication only: Suppl2.pdf

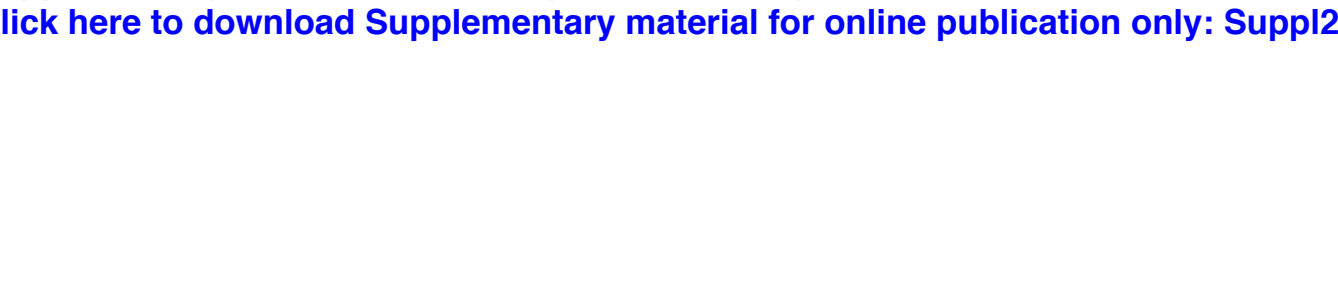
y

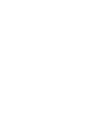

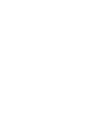
ren -

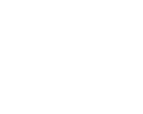

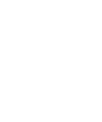

